\title{
Krzywo, prosto, byle ostro - wzrost i naprowadzanie aksonów wzgórzowo-korowych
}

\section{STRESZCZENIE}

W zgórze, główna część międzymózgowia, jest węzłem integrującym informacje zmysłowe, motoryczne i o stanie emocjonalnym. Jako część neuronalnych pętli wzgórzowo-korowych zaangażowane jest $w$ odbiór $i$ analizę bodźców, regulację uwagi i poziomu świadomości oraz wybór reakcji behawioralnej. Rozwój aksonów wzgórzowo-korowych jest krytyczny dla pracy całego mózgu, a ich zaburzenia są jedną z możliwych przyczyn występowania zaburzeń psychicznych u ludzi. Proces topograficznego nakierowywania aksonów wzgórza do kory podlega regulacji przez cząsteczki sygnałowe obecne na drodze rosnących wypustek. W poniższym artykule na przykładzie myszy przybliżymy mechanizmy molekularne odpowiedzialne za wzrost i naprowadzanie aksonów wzgórzowo-korowych w czasie embriogenezy oraz odtworzymy ten proces od momentu wyrastania pierwszych aksonów ze wzgórza do ich wrastania w odpowiednie rejony kory mózgu.

\section{WSTĘP}

Ewolucja poruszających się organizmów wielokomórkowych ściśle wiąże się $\mathrm{z}$ rozwojem centralnego systemu zbierającego informacje zmysłowe i koordynującego ruchy. Wraz ze wzrostem złożoności układu nerwowego rosną możliwości procesowania i integracji informacji, pojawiają się coraz bardziej różnorodne emocje oraz zachodzą coraz bardziej zaawansowane procesy poznawcze. Przekłada się to na szerszy repertuar i większą elastyczność reakcji behawioralnych.

U zwierząt kręgowych centralny układ nerwowy tworzą rdzeń kręgowy i mózg, powstające w czasie ontogenezy z prostej cewki nerwowej. Dojrzały mózg dzieli się na odgraniczone anatomicznie struktury oraz cytoarchitektonicznie wyróżnialne warstwy i jądra. Tym strukturom przypisuje się różne funkcje: kora mózgu to rozumowanie, ciało migdałowate to emocje, jądra podstawy to motywacja, wzgórze to przesyłanie informacji zmysłowych do kory mózgu, hipokamp to pamięć, itd. Nie jest to najlepsze ujęcie, ponieważ na przetwarzanie i ocenę dochodzących informacji oraz wywołanie reakcji behawioralnej składa się połączona praca różnych struktur. Ważne jest więc „uzwojenie” mózgu. Jednostką funkcjonalną mózgu nie jest pojedyncza struktura, ale pętle neuronalne pomiędzy strukturami.

Fizyczną podstawą pętli neuronalnych są połączenia aksonalne, często miedzy niesąsiadującymi obszarami mózgu. Trakty uporządkowanych włókien nerwowych rozwijają się $\mathrm{w}$ czasie embriogenezy. Takie uporządkowanie wymaga ścisłego naprowadzania aksonów w czasie ich wzrostu. W niniejszej pracy przedstawimy mechanizmy molekularne regulujące ten proces na przykładzie rozwoju połączeń pomiędzy wzgórzem a korą mózgu. Omówimy także znaczenie tych połączeń $w$ analizie $i$ integracji informacji zmysłowej oraz funkcjach wykonawczych mózgu.

W ostatnich latach wzgórze budzi coraz większe zainteresowanie, ponieważ dysfunkcje jego połączeń zaobserwowano w przebiegu wielu chorób psychicznych, a terapie oparte na głębokiej stymulacji wzgórza są nadzieją dla osób cierpiących na zaburzenia lekooporne, do czego wrócimy na koniec.

\section{PĘTLE WZGÓRZOWO-KOROWE JAKO PRZYKŁAD FUNKCJONALNEGO UKŁADU MÓZGU}

Wzgórze jest silnie konserwowaną ewolucyjnie częścią mózgu kręgowców [1], zlokalizowaną w centralnej części mózgowia (Ryc. 1). Wzgórze dzieli się na kilkadziesiąt jąder (komórkowych skupisk), odróżniających się od siebie m.in. wielkością i gęstością upakowania komórek oraz wzorem ekspresji markerów genetycznych [2-4]. U owodniowców wszystkie jądra wzgórza wysyłają projekcje do kory mózgu: każde jądro do ściśle określonego obszaru funkcjonalne-

\section{mgr Marcin Andrzej} Lipiec, $^{1,2, \square}$

\section{dr hab. Marta Barbara Wiśniewska $^{1, \varpi}$}

${ }^{1}$ Laboratorium Neurobiologii Molekularnej, Centrum Nowych Technologii, Uniwersytet Warszawski, ul. Banacha 2c, 02-097 Warszawa, tel. +(48) 22 554-36-90 ${ }^{2}$ Wydział Biologii, Uniwersytet Warszawski, ul. Ilji Miecznikowa 1, 02-096 Warszawa

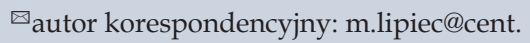
uw.edu.pl

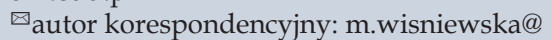
cent.uw.edu.pl

https://doi.orgs/ 10.18388/pb.2019_248

Słowa kluczowe: neurobiologia, wzgórze, aksony wzgórzowo-korowe, wzrost i naprowadzanie aksonu, białka adhezji komórkowej, cząsteczki sygnałowe

Wykaz stosowanych skrótów: CAMs - białka adhezji komórkowej ( $\mathrm{z}$ ang. cell adhesion molecules); Cx - kora mózgu (łac. cortex); EGL - wyniosłość boczna (łac. eminentia ganglionaris lateralis); EGM - wyniosłość środkowa (łac. eminentia ganglionaris medialis); HyTh - podwzgórze (łac. hypothalamus); PTh - przedwzgórze (łac. prethalamus); TCAs - aksony wzgórzowo-korowe ( $\mathrm{z}$ ang. thalamocortical axons); Th - wzgórze (łac. thalamus); VTel - brzuszne kresomózgowie (łac. area ventralis telencephali)

Podziękowania: Praca powstała w wyniku realizacji projektu badawczego o $\mathrm{nr}$ 2016/23/N/ NZ3/02930 finansowanego ze środków Narodowego Centrum Nauki. 


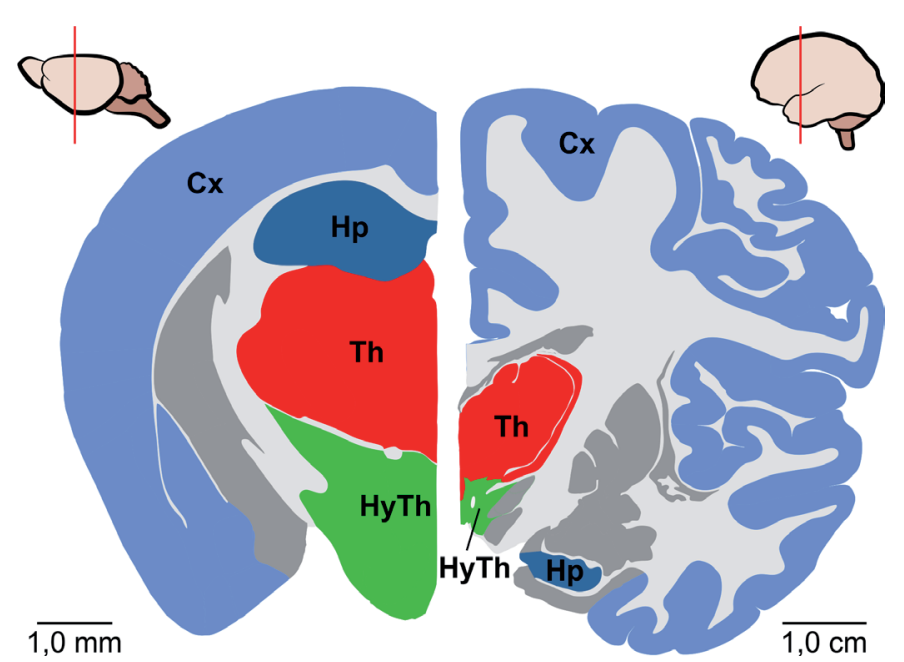

Rycina 1. Przekroje półkul mózgu myszy (strona lewa) i człowieka (strona prawa). Rzut koronalny - płaszczyzna i przybliżone miejsca cięcia zaznaczone czerwoną linią na schematach mózgów w górnej części figury. Cx - kora mózgu; Hp - hipokamp; Th - wzgórze; HyTh - podwzgórze. Rysunek wykonany na podstawie atlasu mózgu myszy i człowieka dostępnych w Allen Brain Atlas [59].

go kory. Nie ma obszaru kory, który nie byłby unerwiony przez aksony neuronów wzgórza i odwrotnie, wszystkie jądra wzgórza otrzymują korową impulsację modulującą [5].

Najlepiej poznaną funkcją wzgórza jest przekazywanie do kory bodźców zmysłowych, docierających do niego nerwami czaszkowymi i drogami rdzenia kręgowego. Informacje wzrokowe, słuchowe, czuciowe, smakowe, a także o czuciu trzewnym, równowadze i czuciu przestrzennym w pierwszej kolejności trafiają do właściwych dla nich jąder wzgórza, a dopiero z nich aksonami wzgórzowo-korowymi przesyłane są do odpowiednich rejonów kory [5-7]. Wzgórze bywa nazywane główną stacją przekaźnikową informacji zmysłowej. Wbrew temu jednak co sądzono jeszcze 30 lat temu, a co wciąż jeszcze można przeczytać w wielu podręcznikach, nie jest to jedyna, a nawet najważniejsza rola wzgórza [8]. Po pierwsze, wzgórze nie tylko przesyła, ale także blokuje lub moduluje informacje zmysłowe. Po drugie, w przekazywanie informacji zmysłowych zaangażowanych jest tylko część jąder, zwanych jądrami pierwszorzędowymi. Dużo większa część wzgórza otrzymuje impulsację napędową nie z dróg sensorycznych ale z kory mózgu. Są to tzw. jądra wyższego rzędu, których funkcją jest przekazywanie informacji pomiędzy różnymi obszarami kory [9]. Te korowo-wzgórzowo-korowe połączenia występują równolegle do połączeń korowo-korowych we wszystkich częściach kory: sensorycznych, motorycznych, limbicznych (związanych z emocjami) i asocjacyjnych. Niektóre jądra wyższego rzędu otrzymują dodatkowo impulsację z podkorowych obszarów motorycznych oraz układu limbicznego. Ta część wzgórza bierze udział w inicjowaniu reakcji behawioralnych [10-14].

We współczesnym ujęciu wzgórze moduluje i przekazuje informację sensoryczną i motoryczną do kory mózgu oraz pośredniczy i wpływa na komunikację między pierwszorzędowymi a asocjacyjnymi rejonami kory. Jako węzeł obwodów podkorowo-korowych wzgórze zaangażowane jest w ukierunkowywanie uwagi, koncentrację, regulację stanu czuwania i poziomu świadomości [15-18]. W pętlach koro- wo-wzgórzowo-korowych zachodzi planowanie, procesowanie pamięci, kontrola zachowań i podejmowanie decyzji o reakcji behawioralnej [19-21]. Nie byłoby to możliwe bez uorganizowanych połączeń wzgórzowo-korowych, precyzyjnie łączących odpowiednie partie wzgórza i kory.

\section{CZYNNIKI NAPROWADZAJĄCE AKSONY WZGÓRZOWO-KOROWE}

Pierwsze aksony wzgórzowo-korowe (ang. thalamocortical axons, TCAs) wyrastają u myszy ze wzgórza już około 11 dnia embrionalnego (E11), czyli krótko po pojawieniu się w zalążku wzgórza pierwszych neuronów. Aby dotrzeć do kory mózgowej, wydłużające się aksony wzgórzowo-korowe podlegają precyzyjnemu naprowadzaniu ze strony różnorodnych cząsteczek sygnałowych oddziałujących na ich stożki wzrostu.

Stożek wzrostu jest wyspecjalizowaną strukturą komórkową z przodu aksonu, umożliwiającą jego dalszy wzrost i nakierowywanie do miejsc docelowych. Dzieli się na dwa główne regiony - centralny i brzeżny (Ryc. 2). W rejonie centralnym znajdują się organelle niezbędne do wzrostu aksonu i dominuje cytoszkielet złożony z mikrotubul. Cytoszkielet części brzeżnej tworzą przede wszystkim filamenty aktynowe, skoncentrowane zwłaszcza od strony krawędzi wiodącej.
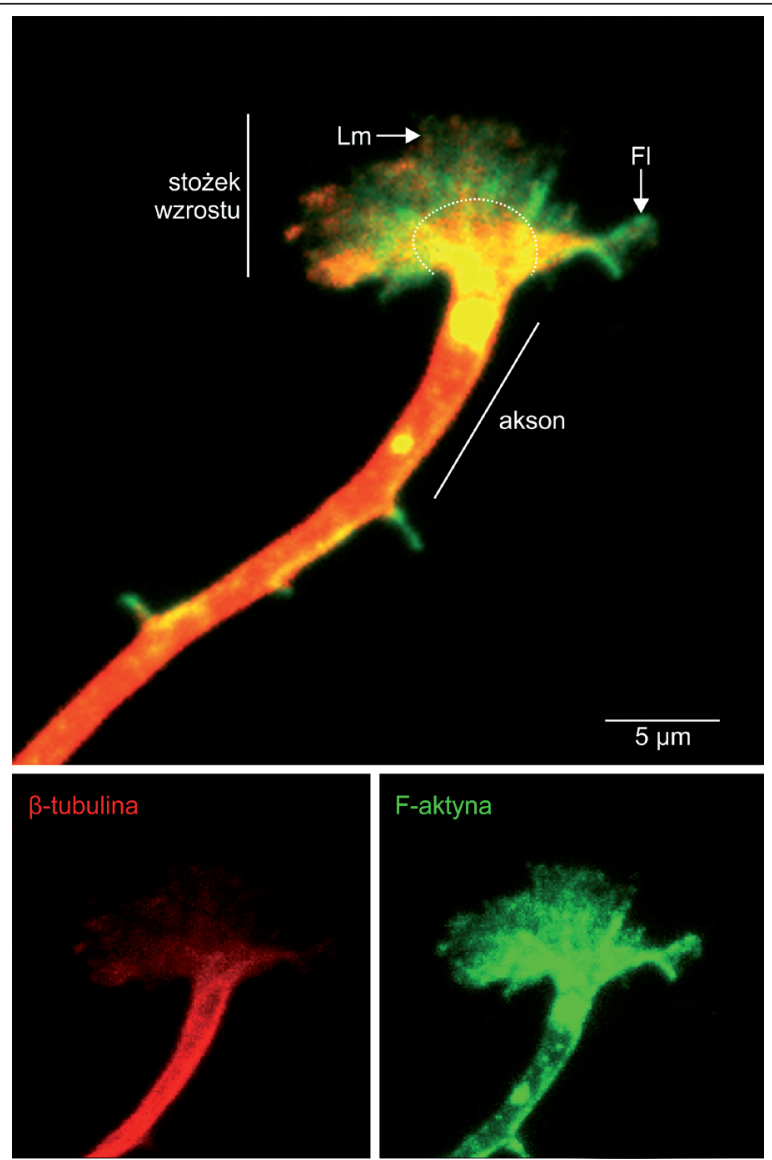

Rycina 2. Akson zakończony stożkiem wzrostu. Zdjęcie rosnącego aksonu neuronu $\mathrm{z}$ mysiej siatkówki w hodowli in vitro wykonane przy pomocy mikroskopu konfokalnego. W obrębie dojrzałej części aksonu dominują mikrotubule, tutaj wyznakowane na czerwono przy użyciu przeciwciała specyficznego dla $\beta$-tubuliny klasy III. W stożku wzrostu dominuje cytoszkielet aktynowy, wyznakowany na zielono przez wiązanie z oznaczoną fluorescencyjnie falloidyną. Przerywaną linią oznaczono przybliżoną granicę między częścią centralną a brzeżną stożka wzrostu. Lm - lamellopodia; Fl - filopodia. Fot. Marcin A. Lipiec. 
Postępująca polimeryzacja aktyny prowadzi do wytworzenia dwóch rodzajów wypustek stożka wzrostu - lamellopodiów i filopodiów. Lamellopodia wyglądem przypominają rozpostartą plechę grzyba, podczas gdy filopodia, wysuwające się dalej i bardziej precyzyjnie od lamellopodiów, przypominają cienkie palce. Na błonie komórkowej obu rodzajów wypustek występuje dużo różnych białek adhezji komórkowej, błonowych ligandów oraz receptorów dla cząstek sygnałowych. Oddziaływanie tych błonowych białek z obecnymi w środowisku czynnikami wzrostu i naprowadzania aksonów skutkuje bezustannym ruchem, wzrostem i cofaniem się wypustek stożka w poszukiwaniu właściwej dla aksonu ścieżki. Procesy te zależą od dynamicznych reorganizacji cytoszkieletu, zwłaszcza włókien aktynowych [22]. Część z tych czynników wydzielana jest do macierzy zewnątrzkomórkowej, gdzie tworzą gradient sygnału wokół miejsca sekrecji. Inne pozostają na powierzchni wyrażających je komórek jako błonowe ligandy, i te oddziałują na stożek wzrostu aksonu w momencie jego fizycznego kontaktu z komórką. Poniżej przybliżamy te rodziny cząsteczek, które odgrywają największą rolę w naprowadzaniu aksonów wzgórzowo-korowych.

\section{SLIT - ROBO}

Białka z rodziny Slit należą do sekrecyjnych chemorepelentów dla migrującego stożka wzrostu aksonu [23]. U większości kręgowców występują trzy białka z tej rodziny - Slit1-3. Każde $\mathrm{z}$ nich składa się z czterech domen bogatych w leucynę (ang. leucine-rich repeat, LRR), siedmiu do dziewięciu motywów naskórkowego czynnika wzrostu (ang. epidermal growth factor, EGF), domeny ALPS (agryna, perlekan, laminina, Slit) lub domeny podobnej do lamininy G oraz węzła cysteinowego na C-końcu. Białka Slit oddziałują z błonowymi receptorami z rodziny Roundabout (Robo). Część zewnątrzkomórkową Robo tworzy pięć domen immunoglobulinopodobnych (Ig) i trzy motywy fibronektynowe typu III (FnIII), a część wewnątrzkomórkową cytoplazmatyczny ogon zawierają kilka motywów CC (ang. cytoplasmic conserved). Białka te mają wiele alternatywnych form splicingowych i podlegają licznym modyfikacjom potranslacyjnym, co dodatkowo zwiększa ich zróżnicowanie. Wiązanie białek Slit do receptorów Robo odbywa się przez oddziaływanie LLR z domenami Ig w Robo. Wiązanie to może być dodatkowo stabilizowane oddziaływaniem kompleksu z siarczanem heparanu - polisacharydem obecnym na powierzchni błon komórek.

Wiązanie Slit wywołuje zmiany konformacyjne białka Robo, przez co wyeksponowane zostaje miejsca cięcia Robo dla zewnątrzkomórkowej metaloproteinazy ADAM10 (ang. a disintegrin and metalloprotease domain containing protein). Cięcie proteolityczne i „złuszczenie” receptora Robo jest niezbędne dla aktywacji jego domeny cytoplazmatycznej i inicjacji kaskady sygnałowej. Efektorami aktywowanego w ten sposób szlaku są GTPazy, na przykład RhoA, które oddziałując z białkami wiążącymi aktynę wpływają na polimeryzację i depolimeryzację włókien aktynowych, co prowadzi do zmiany kierunku wzrostu aksonu.

Białka Slit także mogą być przecinane przez niezidentyfikowany do tej pory enzym. Odcięty fragment zawierający N-koniec Slit wiąże się z receptorami Robo, tak jak białko pełnej długości. Pozostały krótki fragment C-końca Slit ma zdolność wiązania się do pleksyny A1, receptora semaforyn opisanych w dalszej części. Pokazano, że takie oddziaływanie indukuje cofanie się stożków wzrostu aksonów spoidłowych w mysim rdzeniu kręgowym.

\section{EFRYNY - RECEPTORY EPH}

Receptory EPH (ang. erythropoietin-producing hepatocellular receptor) są największą grupą receptorowych kinaz tyrozynowych. Jej 14 członków należy do jednej z dwóch podrodzin - EPHA oraz EPHB. Ligandy receptorów EPH, czyli efryny, także dzielą się na podrodziny A i B. Efryny A i B aktywują głównie receptory swojej podgrupy (odpowiednio EPHA i EPHB), ale dochodzić też może do wiązania niektórych receptorów z przeciwnej rodziny. Zarówno ligandy, jak i receptory EPH są białkami transbłonowymi [24].

Struktura receptorów EPHA i EPHB jest zbliżona, podczas gdy struktury ligandów, efryn A i B, znacząco się między sobą różnią. Część zewnątrzkomórkowa receptorów EPH składa się z domeny wiązania ligandów, domeny bogatej w cysteinę i dwóch powtórzeń FnIII. Część cytoplazmatyczną stanowią przybłonowa domena niezbędna do aktywacji receptora, domena kinazowa, domena SAM (ang. sterile alpha motif) i domena PDZ. Efryny A składają się wyłącznie z domeny wiązania receptora, który zakotwiczony jest w błonie komórkowej glikozylofosfatydyloinozytolem. Efryny B są większe. Składają się z zewnątrzkomórkowej domeny wiązania receptora, domeny transmembranowej oraz krótkiej domeny cytoplazmatycznej z ewolucyjnie konserwowanymi aminokwasami tyrozynowymi i motywem wiązania domeny PDZ.

Jako, że zarówno receptory EPH jak i ich ligandy są białkami błonowymi, do aktywacji ścieżki sygnałowej efryna-EPH niezbędny jest fizyczny kontakt między eksponującymi je komórkami. Aktywacja ścieżki sygnałowej zachodzić może w obu kierunkach, czyli zarówno w komórce wyrażającej receptor, jak i tej prezentującej ligand [25]. Ścieżka indukowana w komórce wyrażającej receptor EPH nazywana jest ścieżką kanoniczną lub forward. Związanie liganda powoduje klastrowanie receptorów EPH i ich transfosforylację $\mathrm{w}$ cytoplazmatycznej domenie kinazowej. To z kolei umożliwia wiązanie białek $\mathrm{z}$ domenami PDZ, SAM lub SH2 (z ang. Src homology 2), co inicjuje kaskadę sygnałową. Białkami docelowymi tej ścieżki są m. in. GTPazy z rodziny Rho: RhoA, Rac1 i Cdc42. Ścieżka sygnałowa efryna-EPH ma wpływ na migrację zarówno aksonów, jak i całych komórek poprzez przebudowę w cytoszkielecie aktynowym. Na przykład aktywacja ścieżki przez efrynę A5 w stożku wzrostu powoduje jego odepchnięcie lub całkowite cofnięcie się [26], spowodowane skurczem komórki i zahamowaniem formacji lamellopodiów. Mniej poznana jest ścieżka aktywowana w komórce prezentującej ligand, nazywana ścieżką reverse. Jej aktywacja wpływa nie tyle na nakierowywanie aksonów, co na adhezję komórkową

\section{NETRYNA 1 - DCC/UNC5}

Spośród kilku przedstawicieli netryn najlepiej scharakteryzowana i opisana pod względem roli w naprowadzaniu 
aksonów jest netryna 1 . Zależnie od kontekstu molekularnego może ona działać jako chemoatraktant lub jako chemorepelent [27]. Netryna 1, podobnie jak reszta członków tej rodziny, składa się z domeny lamininopodobnej, trzech powtórzeń EGF i C-końcowej domeny netrynopodobnej. Białko to jest ligandem dla receptorów Unc5 i DCC (ang. deleted in colorectal cancer). DCC jest receptorem błonowym należącym do nadrodziny immunoglobulin. Złożony jest z czterech domen Ig na końcu N, sześciu powtórzeń FnIII, domeny transbłonowej i około 350-aminokwasowej części wewnątrzkomórkowej o niezdefiniowanej strukturze z trzema konserwowanymi ewolucyjnie motywami P1-P3. Unc5 jest białkiem transbłonowym. Zbudowane jest z dwóch domen Ig, dwóch domen trombospondynowych typu 1 i około 550-aminokwasowego fragmentu cytoplazmatycznego.

Oddziaływanie zewnątrzkomórkowych domen DCC z netryną 1 prowadzi do homodimeryzacji DCC poprzez motyw P3 jego ogona cytoplazmatycznego. Indukuje to ścieżkę sygnałową prowadzącą do aktywacji kinaz z rodziny Src, a dalej do przebudowy cytoszkieletu stożka wzrostu, co przejawia się jako chemoatrakcja. Z kolei oddziaływanie Unc5 z netryną 1 powoduje chemorepulsję stożka wzrostu aksonu. Do wystąpienia tego efektu istotna jest obecność DCC. Efekt ten nie wynika jednak ze współzawodnictwa receptorów o ligand, a ich kooperacji. Pokazano, że DCC, Unc5 i netryna 1 wspólnie tworzą kompleksy białkowe, a zablokowanie domen zewnątrzkomórkowych DCC wyłącza zarówno chemoatrakcję, jak i chemorepulsję.

\section{SEMAFORYNY - PLEKSYNY/NEUROPILINY}

Do semaforyn należy ponad 20 białek sekrecyjnych, transbłonowych oraz związanych na powierzchni błon komórkowych. Cząsteczki z tej grupy mają wysoce zróżnicowaną budowę, a ich charakterystyczną cechą wspólną jest obecność pojedynczej, bogatej w cysteinę domeny Sema w części zewnątrzkomórkowej białka [28]. Większość semaforyn ma także bogaty w cysteinę motyw PSI (plexin-semaphorin-integrin), położony za domeną Sema. Motyw ten działa jak węzeł cysteinowy, a strukturalnie zbliżony jest do samej domeny Sema.

Semaforyny stanowią ligandy dla kilku różnych rodzin receptorów, a także koreceptorów, wpływających na modulację aktywowanej ścieżki sygnałowej. Większość oddziaływań zachodzi między semaforynami a receptorami z rodziny pleksyn. Pleksyny są dużymi, transbłonowymi białkami z zewnątrzkomórkową domeną Sema, która umożliwia dimeryzację receptora i liganda. Część wewnątrzkomórkowa pleksyn składa się z domen GAP (ang. GTPase-activating protein) i RBD (ang. Rho GTPase binding domain), wiążących GTPazy. Semaforyny oddziałują także z neuropilinami, które dla większości semaforyn stanowią koreceptory niezbędne przy wiązaniu pleksyn i aktywacji ścieżki sygnałowej. Neuropiliny oddziałują z różnymi receptorami, w tym pleksynami i białkami adhezji komórkowej, przez co prawdopodobnie stabilizują wiązanie sie tych białek z ligandami. Semaforyny wiążą się także z receptorami Tim2, CD72, integrynami i proteoglikanami, jednak te oddziaływania nie są tak istotne w kontekście wzrostu aksonów wzgórzowo-korowych.
Ścieżka sygnałowa indukowana przez semaforyny, podobnie jak w przypadku wcześniej opisywanych czynników, prowadzi do przebudowy cytoszkieletu aktynowego. W kontekście naprowadzania aksonów wzgórzowych oddziaływanie semaforyn klasy 3 z neuropilinami skutkuje odepchnięciem lub załamaniem struktury stożka wzrostu [29-31]. W ścieżkę sygnałową semaforyn zaangażowane jest wiele czynników. Jednymi z ważniejszych są wspominane już kilkukrotnie GTPazy. Po dimeryzacji pleksyna oddziałuje poprzez domenę GAP z GTPazami z rodzin Ras i Rap, a poprzez domenę RBD z rodziną GTPaz Rho. Zmiana aktywności GTPaz powoduje reorganizację cytoszkieletu.

\section{NEUREGULINA - ERBB}

Neureguliny zaliczane są do czynników wzrostu i różnicowania. W formie niedojrzałej neureguliny są białkami błonowymi, których część zewnątrzkomórkowa zawiera domenę Ig oraz domenę podobną do EGF. Cięcie proteolityczne (np. przez metaloproteinazy z rodziny ADAM) uwalnia fragment zewnątrzkomórkowy neureguliny, który jest ligandem dla receptorowej kinazy tyrozynowej ErbB. Działając jako chemoatraktant, neuregulina 1 tworzy permisywne środowisko dla wzrostu aksonów wyrażających ErbB4 [32,33].

\section{CZĄSTECZKI ADHEZJI KOMÓRKOWEJ}

W procesy wzrostu i naprowadzania aksonów zaangażowanych jest także wiele cząsteczek adhezji komórkowej (ang. cell adhesion molecules, CAMs) [34]. Rodziny te są wysoce zróżnicowane strukturalnie. Do najlepiej przebadanych CAMs należą kadheryny [35], glikoproteiny z grupy L1 i NCAM (ang. neural cell adhesion molecule), należące do nadrodziny immunoglobulin [36] oraz integryny [37,38]. Kadheryny i immunoglobulinowe białka adhezyjne tworzą międzykomórkowe homodimery zakotwiczone od strony cytoplazmatycznej w cytoszkielecie, natomiast integryny oddziałują przede wszystkim z białkami macierzy zewnątrzkomórkowej. Poza tym, że uczestniczą w adhezji, CAMs wpływają na wzrost aksonu poprzez aktywację ścieżek sygnałowych prowadzących do reorganizacji cytoszkieletu. Na przykład wydłużanie aksonów może być pozytywnie lub negatywnie regulowane przez N-kadherynę, zależnie od kontekstu molekularnego. N-kadheryna oddziałując z $\beta$-kateniną znosi jej hamujący wpływ na białko APC (ang. adenomatous polyposis coli), będące czynnikiem ułatwiającym wydłużanie wypustki. Z drugiej strony, N-kadheryna może oddziaływać z kateniną p120, przez co blokuje zależną od kateniny p120 aktywację GTPaz, a tym samym hamuje wzrost neurytów. NCAM wpływa na polimeryzację mikrotubul przez oddziaływanie z białkiem MAP1 (ang. microtubule-associated protein-1) i tubuliną. L1CAM i CHL1 (ang. cell adhesion molecule L1 like) powodują reorganizację cytoszkieletu przez oddziaływanie ze spektrynami, które tworzac szkielet spektrynowy i oddziałują z aktyną. Oddziaływanie białek L1 z integrynami może dodatkowo aktywować ścieżkę MAPK, a za jej pośrednictwem wpływać na ekspresję genów związanych ze wzrostem aksonów. Opisano tu jedynie niektóre cząsteczki adhezji komórkowej i niewielki wycinek indukowanych przez nie procesów. 


\section{NAPROWADZANIE POŁACZEŃ WZGÓRZOWO- KOROWYCH NA PRZYKŁADZIE MYSZY}

\section{POCZĄTKOWY WZROST AKSONÓW WZGÓRZOWO-KOROWYCH}

Jak wspomniano, aksony pierwszych neuronów wzgórza zaczynają droge prowadzącą do kory około E11 [39-41]. Początkowo rosną w stronę przedwzgórza (łac. Prethalamus, PTh) (Ryc. 3). Po jego przecięciu kierują się dalej w dół w stronę podwzgórza (łac. Hypothalamus, HyTh).

Niewiele wiadomo o tym, jakie czynniki inicjują ten proces i jak aksony wzgórzowo-korowe określają swoją pierwotną trajektorię. Możliwe, że postmitotyczne neurony wzgórza różnicują w określonej polarności, a wyrastające $\mathrm{z}$ nich aksony od początku skierowane są w stronę PTh. Możliwe też, że za utrzymanie właściwej trajektorii odpowiadają oddziaływania z napotkanymi aksonami PTh migrującymi do wzgórza. Jest to tak zwana hipoteza handshake, według której wiązki aksonów kolejno się spotykają i kierują nawzajem, niczym po raz już przetartej ścieżce $[40,42]$.

Zanim TCAs dotrą do HyTh gwałtownie skręcają nieomal o $180^{\circ} \mathrm{w}$ kierunku VTel, czyli subpallium (Ryc. 4). Spowodowane jest to wysoką ekspresją białka Slit2 w HyTh, które wywołuje chemorepulsję stożków wzrostu aksonów wzgórza wyrażających Robo. Oddziaływanie to „popycha" stożki wzrostu do granicy między międzymózgowiem

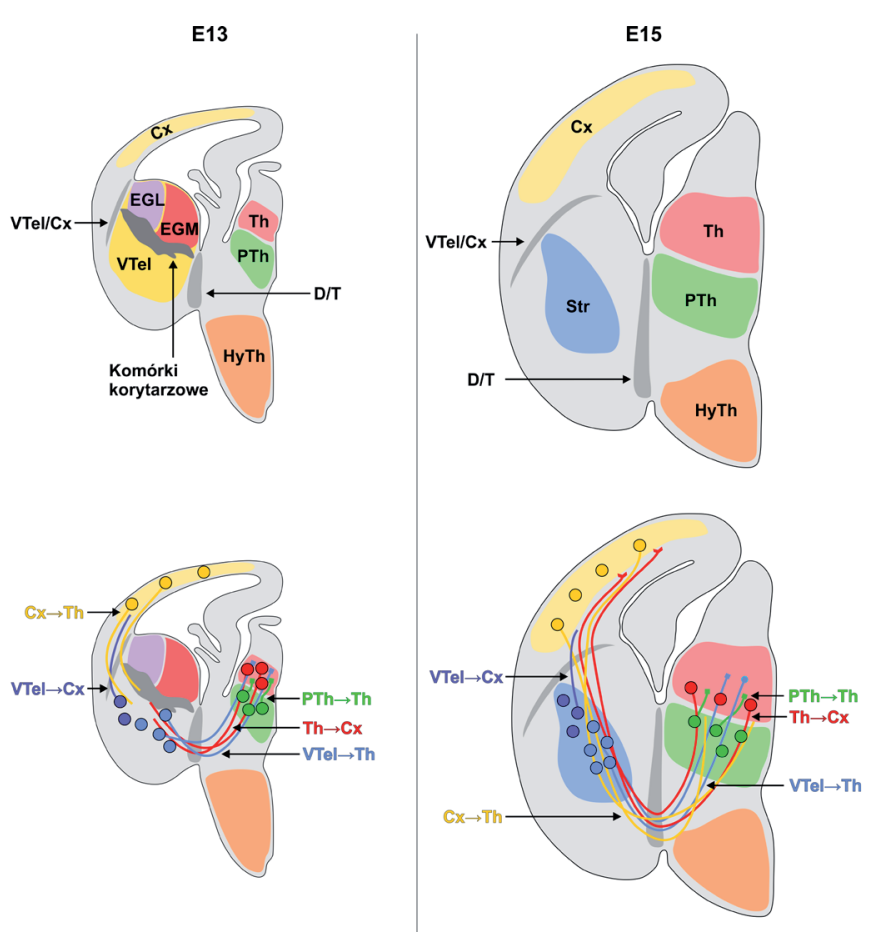

Rycina 3. Referencyjna anatomia oraz rozwój mózgu i połączeń nerwowych w przodomózgowiu u myszy E13 i E15. Cx - kora mózgu, Th - wzgórze; PTh - przedwzgórze; HyTh - podwzgórze; EGM - wyniosłość środkowa; EGL - wyniosłość boczna; VTel - brzuszne kresomózgowie; D/T - granica pomiędzy międzymózgowiem (diencephalon) i kresomózgowiem (telencephalon); VTel/Cx - granica pomiędzy brzusznym kresomózgowiem i korą; Str - prążkowie; PTh $\rightarrow$ Th - aksony przedwzgórzowo-wzgórzowe; $\mathrm{Th} \rightarrow \mathrm{Cx}$ - aksony wzgórzowo-korowe $\mathrm{VTel} \rightarrow \mathrm{Th}$ - aksony brzusznego kresomózgowia do wzgórza; Cx $\rightarrow$ Th - aksony korowo-wzgórzowe; VTel $\rightarrow \mathrm{Cx}$ - aksony brzusznego kresomózgowia do kory. Zmodyfikowany rysunek oparty na [40]

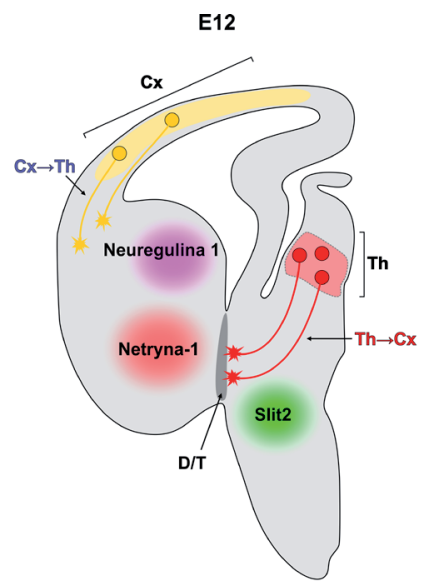

Rycina 4. Sygnały naprowadzające aksony wzgórzowo-korowe. Schemat przedstawia półkule mysiego mózgu w rzucie koronalnym około E12. Wyrażany w podwzgórzu Slit2 jest chemorepelentem dla aksonów wzgórzowo-korowych, odpychającym stożki wzrostu w stronę VTel. Za wczesną chemoatrakcję aksonów wzgórzowo-korowych do VTel odpowiadać może netryna 1. Neuregulina 1 wydzielana przez komórki korytarzowe tworzy środowisko permisywne dla wzrostu aksonów wzgórzowych przez VTel. Th - wzgórze; Cx - kora mózgu; $\mathrm{Th} \rightarrow \mathrm{Cx}$ - aksony wzgórzowo-korowe; $\mathrm{Cx} \rightarrow \mathrm{Th}$ - aksony korowo-wzgórzowe; $\mathrm{D} / \mathrm{T}$ - granica pomiędzy międzymózgowiem (diencephalon) i kresomózgowiem (telencephalon). Zmodyfikowana rycina oparta na $[39,60]$.

a kresomózgowiem. Tutaj także zachodzi handshake aksonów: w naprowadzaniu TCAs biorą udział aksony rosnące z VTel w kierunku wzgórza. Pokazano, że zaburzenie wzrostu tych aksonów, np. u myszy z nokautem genów rozwojowych wyrażanych poza wzgórzem (lub nokautem tkankowo-specyficznym) Ascl1, Pax6, Lhx2 lub Emx2 sprawia, że TCAs w ogóle nie wchodzą do VTel lub wykazują błędną nawigację przez tę strukturę.

\section{WZROST AKSONÓW WZGÓRZOWO-KOROWYCH PRZEZ BRZUSZNE KRESOMÓZGOWIE}

Około E13-E14 TCAs zwartymi wiązkami rosną w kierunku dziobowym przez VTel. W skład tego regionu na tym etapie rozwojowym wchodzac przejściowe struktury, m.in. wyniosłość boczna (łac. eminentia ganglionaris lateralis, EGL) i wyniosłość środkowa (łac. eminentia ganglionaris medialis, EGM). Istotnym czynnikiem zaangażowanym w kierowanie aksonów wzgórzowo-korowych przez VTel są komórki „korytarzowe”. Są to pochodzące z EGL niedojrzałe neurony GABAergiczne, które migrując do EGM między E11 a E14 tworzą po drodze swoisty korytarz. Za zdolność komórek korytarzowych do prowadzenia aksonów wzgórza odpowiada, przynajmniej po części, zachodząca w nich ekspresja neureguliny 1 . Neuregulina 1 oddziałuje $\mathrm{z}$ receptorem ErbB4 wyrażanym przez aksony wzgórzowe, które bez jej udziału nie są w stanie przejść przez EGM.

\section{SEGREGACJA AKSONÓW WZGÓRZOWO- KOROWYCH W BRZUSZNYM KRESOMÓZGOWIU}

Wędrujące przez VTel aksony wzgórza ulegają stopniowej segregacji, zależnej od miejsca ich pochodzenia (danego jądra wzgórza) i docelowych fragmentów kory. Odpowiadają za to chemoatraktanty i chemorepelenty produkowane przez komórki VTel, m. in. przez komórki korytarzowe: efryny, netryna 1, semaforyny oraz czynniki adhezji komórkowej, w szczególności CAMs z rodziny L1CAM. Ekspresja tej skomplikowanej mieszanki ligandów i ich receptorów jest ściśle kontrolowana 
A
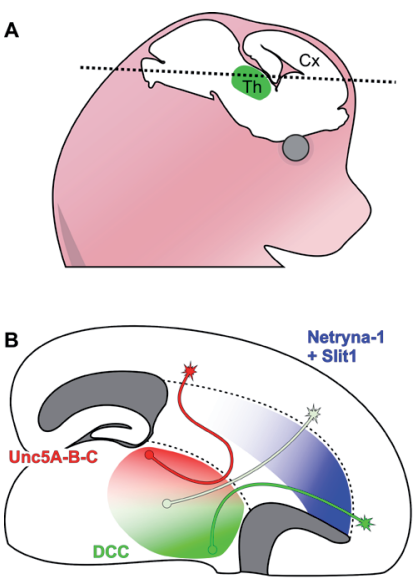
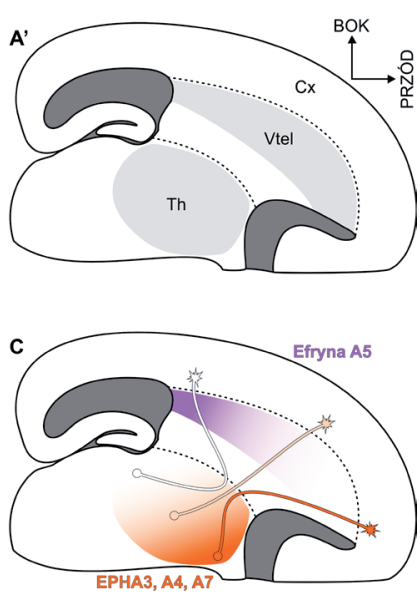

Rycina 5. Model kierowania aksonów wzgórzowo-korowych w brzusznym kresomózgowiu przez netrynę-1/Slit-1 i efrynęA5. A) Płaszczyzna cięcia (zaznaczona przerywaną linia) w prezentowanym rzucie poprzecznym. A') Schemat półkuli mysiego mózgu w rzucie poprzecznym. B) Wysoka ekspresja receptora DCC w przednich partiach wzgórza skutkuje przyciąganiem ich aksonów przez silny gradient netryny-1 w przedniej cześci subpallium. Efekt oddziaływania netryny-1 z DCC modulowany jest przez współobecność Slit1. Białko to oddziałuje z receptorami Robo1 i FLRT3 obecnymi w TCAs z rostralnych partii wzgórza i dodatkowo promuje w nich wysoką ekspresję DCC. Netryna-1 działa z kolei repulsywnie na wyrażające Unc5A-B-C aksony tylnych partii wzgórza. C) Wysoka ekspresja receptorów EPHA w rostralnych częściach wzgórza skutkuje odpychaniem ich aksonów od wyrażajacych efrynę A5 kaudalnych partii brzusznego kresomózgowia. Cx - kora (łac. cortex); VTel - brzuszne kresomózgowie (łac. area ventralis te lencephali); Th - wzgórze (łac. thalamus). Zmodyfikowany rysunek oparty na [61].

przestrzennie, zarówno w podregionach VTel, jak i subpopulacjach aksonów wzgórzowych. Oddziaływania miedzy nimi prowadzą do precyzyjnego sortowania aksonów. Proces naprowadzania aksonów wzgórzowych przez efryny-receptory EPH i netrynę-1/Slit1-DCC/Unc5 przedstawiony został na rycinie 5 . W skrócie, netryna 1 razem ze Slit1 powodują nakierowywanie aksonów przednich jąder wzgórza wyrażających DCC do przednich części kory. Te same czynniki odpychają aksony tylnych jąder wzgórza, wyrażających receptory Unc5. Aksony te dodatkowo nie wyrażają receptorów EPHA3, A4 i A7, przez co są niewrażliwe na odpychanie ze strony obecnej w ogonowej części VTel efryny A5. Ta, odpychająco działa z kolei na aksony przednich partii wzgórza, które oprócz DCC wyrażają także wspomniane receptory EPH. W wywoływaniu przez rodzinę EPH załamania struktury stożka wzrostu pośredniczą L1CAM i CHL1. Kierowanie aksonów wzgórzowych przez semaforyny klasy 3 także modulowane jest przez czynniki adhezji komórkowej z rodziny L1CAM. Semaforyny 3A i 3F wyrażane są $\mathrm{w}$ gradiencie analogicznym do gradientu efryny A5, to znaczy ich ekspresja najsilniejsza jest $\mathrm{w}$ ogonowej części VTel. Wywoływana przez semaforynę 3A chemorepulsja zależy od wiązania jej receptora - neuropiliny 1 przez CHL1. Do załamania struktury stożka wzrostu potrzebne jest z kolei wiązanie CHL1 z białkami ERM - ezryną, radyksyną, moezyną (łącznikami między filamentami aktynowymi a błoną komórkową) lub wiązanie neuropiliny 1 z L1CAM. Analogicznie, chemorepulsja wywoływana przez semaforynę $3 \mathrm{~F}$ wymaga wiązania NrCAM do neuropiliny 2.

Na proces kierowania aksonów wzgórza wpływ ma też aktywność elektryczna jego neuronów. W embrionalnym wzgórzu wcześnie zaczyna dochodzić do spontanicznych wyładowań o zmiennej częstotliwości. Pokazano, że zmien-

na częstotliwość aktywności elektrycznej reguluje ekspresję genów Robo1 i Dcc. Robo1 działa hamująco na wzrostu aksonów, podczas gdy DCC wzrost ten przyśpiesza. Szybki wzrost połączeń wzgórzowych wiązany jest z wyładowaniami o dużej częstotliwości, co ma miejsce podczas ich wędrówki przez VTel. Po wejściu do kory aksony zwalniają, tak jak obniża się częstotliwość wyładowań.

\section{WZROST AKSONÓW WZGÓRZOWO- KOROWYCH W KORZE MÓZGU}

Około E13 pierwsze aksony wzgórza docierają do granicy pomiędzy korą mózgu (pallium) a VTel. Do tego czasu obszar ten jest już gęsto zasiedlony przez wypustki komórek progenitorowych i przecinające trasę TCAs neurony migrujące $\mathrm{m}$. in. $\mathrm{z}$ granicy kory i VTel do ciała migdałowatego $i$ kory gruszkowatej. Tworzy to trudne do przeniknięcia środowisko, którego przejście ułatwiają aksony korowo-wzgórzowe, które wcześniej docierają do granicy kora-VTel niż aksony wzgórzowo-korowe. Pokazano, że u transgenicznych myszy niewykształcających aksonów korowych, prawidłowo posegregowane $\mathrm{w}$ VTel aksony wzgórza trwale utykają na granicy z korą [43].

Po wkroczeniu na teren kory, w jej dolnej warstwie pośredniej (łac. zona intermedia, ZI), stożki wzrostu TCAs ulegają przebudowie. Następnie TCAs podejmują wzrost $\mathrm{w}$ innym kierunku, rozchodzą się radialnie $\mathrm{w}$ warstwie podpłytkowej (łac. zona sublaminaris, najwcześniej wytworzona, tymczasowa warstwa kory) i docierają do docelowych obszarów w topograficznie uporządkowany sposób. W efekcie tego aksony z danego jądra wzgórza trafiają do określonych obszarów kory. W tym okresie dochodzi do bardzo intensywnego rozwoju kory: proliferacji i różnicowania komórek progenitorowych, migracji interneuronów z EGL i EGM, zmian anatomicznych i wyodrębniania się kolejnych warstw kory. Początkowo TCAs akumulują się więc we wspomnianej warstwie podpłytkowej, a dopiero po 2-3 dniach oczekiwania (około E16) zaczynają wrastać we właściwe warstwy kory, gdzie tworzą liczne odgałęzienia i synapsy. Ten etap kończy się dopiero około tygodnia po urodzeniu. Jednymi z czynników odpowiedzialnych za segregację TCAs w korze są efryny, różnicowo wyrażane w poszczególnych jądrach wzgórza i warstwach kory. Na przykład efryna A5 silnie wyrażana jest w IV i VI warstwie kory somatosensorycznej, a efryna A4 w jej warstwie pośredniej. EPHA7 wyrażana jest $\mathrm{z}$ kolei $\mathrm{w}$ specyficznym gradiencie $\mathrm{w}$ warstwach V i VI kory somatosensorycznej, wzrokowej i słuchowej. Efryna A5 także obecna jest w korze somatosensorycznej, wzrokowej i słuchowej, ale tworzone przez nią gradienty ekspresji są dokładnie odwrotne od EPHA7 [44].

\section{REGULACJA WZROSTU I NAPROWADZANIA AKSONÓW WZGÓRZOWO-KOROWYCH NA POZIOMIE REGULACJI EKSPRESJI GENÓW}

Dopiero $\mathrm{w}$ ostatnich latach zaczęto zwracać uwagę na kontrolę procesu naprowadzania aksonów wzgórzowo-korowych przez czynniki transkrypcyjne, wyrażane specyficznie w całym wzgórzu lub niektórych jego jądrach. Pokazano, że w ukierunkowany wzrost TCAs zaangażowane są indukowane w czasie neurogenezy GBX2 [45], TCF7L2 [46, 47], LHX2 [48] oraz FOXP2 [49]. Nokaut Foxp2 
lub Lhx2 powoduje zaburzenia trajektorii wzrostu aksonów z określonych części wzgórza: części tylnej u myszy Foxp21- i przedniej u myszy Lhx2-\%, natomiast nokaut genów Gbx2 i Tcf7l2 prowadzi do całkowitego braku połączeń między wzgórzem a korą. U myszy Gbx2-- aksony wzgórzowe nieprawidłowo wrastają $\mathrm{w}$ brzuszną część śródmózgowia i grzbietową międzymózgowia, a u myszy Tcf7l2/- kierują się do podwzgórza. GBX2 bierze udział w ustalaniu pierwotnej trajektorii TCAs poprzez regulację ekspresji czynników transkrypcyjnych LHX2 i LHX9, które z kolei wpływają na ekspresję genów Robo1 i Robo2. TCF7L2 także reguluje geny kodujące białka adhezyjne i naprowadzające aksony, m. in. $z$ rodziny $\mathrm{ROBO}$, kadheryn i receptorów EPHA, oraz szereg genów kodujących wzgórzowe czynniki transkrypcyjne, $\mathrm{w}$ tym. GBX2, FOXP2 i LHX2. Wskazuje to na hierarchiczną specyfikację trajektorii wzrostu aksonów z różnych części wzgórza.

\section{DYSFUNKCJE POŁACZEŃ WZGÓRZOWO- KOROWYCH W ZABURZENIACH PSYCHICZNYCH}

Związek między nieprawidłową anatomią wzgórza i dysfunkcjami połączeń wzgórzowo-korowych a występowaniem zaburzeń psychicznych jest bardzo dobrze udokumentowany dzięki badaniom $z$ obrazowaniem dyfuzyjnym i funkcjonalnym mózgu z użyciem rezonansu magnetycznego. Dotyczy to szczególnie schizofrenii, choroby afektywnej dwubiegunowej (ChAD) i zaburzeń ze spektrum autyzmu (ZSA). Etiologia tych chorób nadal nie jest w pełni poznana - są to zaburzenia o podłożu wieloczynnikowym i nie udało się jeszcze zidentyfikować i powiązać ze sobą wszystkich składających się na nie elementów. U osób cierpiących na schizofrenię i ChAD występują zbliżone nieprawidłowości w funkcjonowaniu połączeń wzgórzowo-korowych [50,51]. Zaobserwowano zmniejszoną aktywność połączeń z korą przedczołową, która związana jest $\mathrm{z}$ planowaniem działań, rozumieniem ich konsekwencji i hamowaniem emocji, a zwiększoną aktywność połączeń z korą sensoryczną, sensoryczno-motoryczną i motoryczną $[52,53]$. Badania osób z ZSA wykazały natomiast podwyższoną aktywność połączeń z rejonami kory przedczołowej, razem $\mathrm{z}$ podwyższoną aktywnością połączeń z obszarami sensorycznymi i sensoryczno-motorycznymi [54]. Zarówno u osób ze schizofrenią, jak i ZSA zaobserwowano zmienione tempo integracji informacji zmysłowej i wydłużenie okna czasowego potrzebnego do powiązania informacji audiowizualnych [55]. Możliwą przyczyną tych wszystkich zaburzeń jest nieprawidłowy rozwój połączeń wzgórzowo-korowych, ponieważ w wielkoskalowych badaniach genetycznych jako czynniki ryzyka ZSA i schizofrenii zidentyfikowano geny kodujące białka Slit i Robo, efryny i ich receptory, receptory DCC i Unc5, semaforyny, pleksyny, neuregulinę 1 oraz białka adhezji komórkowej [56-58].

\section{PIŚMIENNICTWO}

1. Butler AB (2008) Evolution of the thalamus: a morphological and functional review. Thalamus \& Related Systems. 4: 35-58

2. Yuge K, Kataoka A, Yoshida AC, Itoh D, Aggarwal M, Mori S, Blackshaw S, Shimogori T (2011) Region-specific gene expression in early postnatal mouse thalamus. J Comp Neurol. 519: 544-61

3. Nagalski A, Puelles L, Dabrowski M, Wegierski T, Kuznicki J, Wisniewska MB (2016) Molecular anatomy of the thalamic complex and the underlying transcription factors. Brain Struct Funct. 221: 2493-510
4. Gezelius H, Moreno-Juan V, Mezzera C, Thakurela S, Rodríguez-Malmierca LM, Pistolic J, Benes V, Tiwari VK, López-Bendito G (2017) Genetic Labeling of Nuclei-Specific Thalamocortical Neurons Reveals Putative Sensory-Modality Specific Genes. Cereb Cortex 27: 5054-5069

5. Guillery RW, Sherman SM (2002) Thalamic relay functions and their role in corticocortical communication: generalizations from the visual system. Neuron 33: 163-75

6. Theyel BB, Llano DA, Sherman SM (2010) The corticothalamocortical circuit drives higher-order cortex in the mouse. Nat Neurosci 13: 84-8

7. Bollimunta A, Mo J, Schroeder CE, Ding M (2011) Neuronal mechanisms and attentional modulation of corticothalamic a oscillations. J Neurosci 31: 4935-43

8. Sherman SM (2016) Thalamus plays a central role in ongoing cortical functioning. Nat Neurosci 19: 533-41

9. Sherman SM (2012) Thalamocortical interactions. Curr Opin Neurobiol 22: 575-9

10. Bezdudnaya T, Keller A (2008) Laterodorsal nucleus of the thalamus: A processor of somatosensory inputs. J Comp Neurol 507: 1979-89

11. Bosch-Bouju C, Hyland BI, Parr-Brownlie LC (2013) Motor thalamus integration of cortical, cerebellar and basal ganglia information: implications for normal and parkinsonian conditions. Front Comput Neurosci 7: 163

12. Saalmann YB (2014) Intralaminar and medial thalamic influence on cortical synchrony, information transmission and cognition. Front Syst Neurosci 8: 3

13. Garcia-Munoz M, Arbuthnott GW (2015) Basal ganglia-thalamus and the "crowning enigma". Front Neural Circuits 9: 71

14. Mo C, Sherman SM (2019) A Sensorimotor Pathway via Higher-Order Thalamus. J Neurosci 39: 692-704

15. Steriade M (2000) Corticothalamic resonance, states of vigilance and mentation. Neuroscience 101: 243-76

16. Basso MA, Uhlrich D, Bickford ME (2005) Cortical function: a view from the thalamus. Neuron 45: 485-8.

17. Saalmann YB, Kastner S (2011) Cognitive and perceptual functions of the visual thalamus. Neuron 71: 209-23

18. Gent TC, Bandarabadi M, Herrera CG, Adamantidis AR (2018) Thalamic dual control of sleep and wakefulness. Nat Neurosci 21: 974-984

19. Jankowski MM, Ronnqvist KC, Tsanov M, Vann SD, Wright NF, Erichsen JT, Aggleton JP, O'Mara SM (2013) The anterior thalamus provides a subcortical circuit supporting memory and spatial navigation. Front Syst Neurosci 7: 45

20. Hsu DT, Kirouac GJ, Zubieta JK, Bhatnagar S(2014) Contributions of the paraventricular thalamic nucleus in the regulation of stress, motivation, and mood. Front Behav Neurosci 8: 73

21. Mitchell AS (2015) The mediodorsal thalamus as a higher order thalamic relay nucleus important for learning and decision-making. Neurosci Biobehav Rev 54: 76-88

22. Chilton JK (2006) Molecular mechanisms of axon guidance. Dev Biol 292: 13-24

23. Blockus H, Chédotal A (2016) Slit-Robo signaling. Development 143: 3037-44

24. Taylor H, Campbell J, Nobes CD (2017) Ephs and ephrins. Curr Biol 27: R90-R95

25. Lisabeth EM, Falivelli G, Pasquale EB (2013) Eph receptor signaling and ephrins. Cold Spring Harb Perspect Biol 5

26. Kullander K, Klein R (2002) Mechanisms and functions of Eph and ephrin signalling. Nat Rev Mol Cell Biol 3: 475-86

27. Finci L, Zhang Y, Meijers R, Wang JH (2015) Signaling mechanism of the netrin-1 receptor DCC in axon guidance. Prog Biophys Mol Biol 118: $153-60$

28. Alto LT, Terman JR (2017) Semaphorins and their Signaling Mechanisms. Methods Mol Biol 1493: 1-25

29. Luo Y, Raible D, Raper JA (1993) Collapsin: a protein in brain that induces the collapse and paralysis of neuronal growth cones. Cell 75: $217-27$ 
30. Fan J, Raper JA (1995) Localized collapsing cues can steer growth cones without inducing their full collapse. Neuron 14: 263-74

31. Luo Y, Shepherd I, Li J, Renzi MJ, Chang S, Raper JA (1995) A family of molecules related to collapsin in the embryonic chick nervous system. Neuron 14: 1131-40

32. Mei L, Nave KA (2014) Neuregulin-ERBB signaling in the nervous system and neuropsychiatric diseases. Neuron 83: 27-49.

33. Ryu J, Hong BH, Kim YJ, Yang EJ, Choi M, Kim H, Ahn S, Baik TK, Woo RS, Kim HS (2016) Neuregulin-1 attenuates cognitive function impairments in a transgenic mouse model of Alzheimer's disease. Cell Death Dis 7: e2117

34. Missaire M, Hindges R (2015) The role of cell adhesion molecules in visual circuit formation: from neurite outgrowth to maps and synaptic specificity. Dev Neurobiol 75: 569-83

35. Jontes JD (2018) The Cadherin Superfamily in Neural Circuit Assembly. Cold Spring Harb Perspect Biol 10

36. Sytnyk V, Leshchyns'ka I, Schachner M (2017) Neural cell adhesion molecules of the immunoglobulin superfamily regulate synapse formation, maintenance, and function. Trends Neurosci 40: 295-308

37. Park YK, Goda Y (2016) Integrins in synapse regulation. Nature Reviews Neuroscience, 17: 745

38. Lilja J, Ivaska J (2018) Integrin activity in neuronal connectivity. J Cell Sci 131

39. López-Bendito G, Molnár Z (2003) Thalamocortical development: how are we going to get there? Nat Rev Neurosci 4: 276-89

40. Molnár Z, Garel S, López-Bendito G, Maness P, Price DJ (2012) Mechanisms controlling the guidance of thalamocortical axons through the embryonic forebrain. Eur J Neurosci 35: 1573-85

41. López-Bendito G (2018) Development of the Thalamocortical Interactions: Past, Present and Future. Neuroscience 385: 67-74

42. Blakemore C, Molnár Z (1990) Factors involved in the establishment of specific interconnections between thalamus and cerebral cortex. Cold Spring Harb Symp Quant Biol 55: 491-504

43. Chen Y, Magnani D, Theil T, Pratt T, Price DJ (2012) Evidence that descending cortical axons are essential for thalamocortical axons to cross the pallial-subpallial boundary in the embryonic forebrain. PLoS One 7: e33105

44. Torii M, Levitt P (2005) Dissociation of corticothalamic and thalamocortical axon targeting by an EphA7-mediated mechanism. Neuron 48: 563-75

45. Chatterjee M, Li K, Chen L, Maisano X, Guo Q, Gan L, Li JY (2012) Gbx2 regulates thalamocortical axon guidance by modifying the LIM and Robo codes. Development 139: 4633-43

46. Lee M, Yoon J, Song H, Lee B, Lam DT, Baek K, Clevers H, Jeong, Y (2017) Tcf7l2 plays crucial roles in forebrain development through regulation of thalamic and habenular neuron identity and connectivity. Dev Biol 424: 62-76
47. Lipiec MA, Koziński K, Zajkowski T, Dąbrowski M, Chakraborty C, Toval A, Ferran JL, Nagalski A, Wiśniewska MB (2019) The transcription factor TCF7L2 functions as a terminal selector in thalamic and habenular regions of the brain. bioRxiv doi: 10.1101/515874

48. Marcos-Mondéjar P, Peregrín S, Li JY, Carlsson L, Tole S, López-Bendito $G$ (2012) The lhx2 transcription factor controls thalamocortical axonal guidance by specific regulation of robo1 and robo2 receptors. J Neurosci 32: 4372-85

49. Ebisu, H., Iwai-Takekoshi, L., Fujita-Jimbo, E., Momoi, T. \& Kawasaki, H. (2016) Foxp2 Regulates Identities and Projection Patterns of Thalamic Nuclei During Development. Cereb Cortex 27: 3648-3659

50. Woodward ND, Karbasforoushan H, Heckers S (2012) Thalamocortical dysconnectivity in schizophrenia. Am J Psychiatry 169: 1092-9

51. Tu PC, Bai YM, Li CT, Chen MH, Lin WC, Chang WC, Su TP (2018) Identification of Common Thalamocortical Dysconnectivity in Four Major Psychiatric Disorders. Schizophr Bull sby166

52. Anticevic A, Cole MW, Repovs G, Murray JD, Brumbaugh MS, Winkler AM, Savic A, Krystal JH, Pearlson GD, Glahn DC (2014) Characterizing thalamo-cortical disturbances in schizophrenia and bipolar illness. Cereb Cortex 24: 3116-30

53. Woodward ND, Heckers S (2016) Mapping Thalamocortical Functional Connectivity in Chronic and Early Stages of Psychotic Disorders. Biol Psychiatry 79: 1016-25

54. Woodward ND, Giraldo-Chica M, Rogers B, Cascio CJ (2017) Thalamocortical dysconnectivity in autism spectrum disorder: An analysis of the Autism Brain Imaging Data Exchange. Biol Psychiatry Cogn Neurosci Neuroimaging 2: 76-84

55. Zhou HY, Cai XL, Weigl M, Bang P, Cheung EFC, Chan RCK (2018) Multisensory temporal binding window in autism spectrum disorders and schizophrenia spectrum disorders: A systematic review and meta-analysis. Neurosci Biobehav Rev 86: 66-76

56. McFadden K, Minshew NJ (2013) Evidence for dysregulation of axonal growth and guidance in the etiology of ASD. Front Hum Neurosci 7: 671

57. Mostaid MS, Lloyd D, Liberg B, Sundram S, Pereira A, Pantelis C, Karl T, Weickert CS, Everall IP, Bousman CA (2016) Neuregulin-1 and schizophrenia in the genome-wide association study era. Neurosci Biobehav Rev 68: 387-409

58. Wang Z, Li P, Wu T, Zhu S, Deng L, Cui G (2018) Axon guidance pathway genes are associated with schizophrenia risk. Exp Ther Med 16 $4519-4526$

59. Allen Brain Atlas API. (2015) Allen Institute for Brain Science. Available online: brain-map.org/api/index.html

60. Garel S, López-Bendito G (2014) Inputs from the thalamocortical system on axon pathfinding mechanisms. Curr Opin Neurobiol 27: 143-50

61. Powell AW, Sassa T, Wu Y, Tessier-Lavigne M, Polleux F (2008) Topography of thalamic projections requires attractive and repulsive functions of Netrin-1 in the ventral telencephalon. PLoS Biol 6: e116

\section{We have to find a way - growth and guidance of thalamocortical axons}

\section{Marcin Andrzej Lipiec ${ }^{1,2}$ Marta Barbara Wiśniewska ${ }^{1}$}

${ }^{1}$ Laboratory of Molecular Neurobiology, Centre of New Technologies, University of Warsaw, Banacha 2c St., 02-097 Warsaw, tel. +(48) 22 554-36-90

${ }^{2}$ Faculty of Biology, University of Warsaw, Ilji Miecznikowa 1 St., 02-096 Warsaw

corresponding author: m.lipiec@cent.uw.edu.pl

corresponding author: m.wisniewska@cent.uw.edu.pl

Keywords: neurobiology, thalamus, thalamocortical axons, growth and guidance factors, cell adhesion molecules, signalling molecules

\section{ABSTRACT}

The thalamus is a major part of the diencephalon and a hub for integrating sensory, motor and emotional information. Thalamocortical neuronal loops are involved in processing of sensory stimuli, directing attention, regulating the level of conscious awareness and selecting behavioural responses. The establishment of topographic thalamo-cortical connections is critical for brain performance, and their dysfunctions can contribute to the development of mental disorders. Thalamic axon guidance is regulated by the expression of molecular cues along the way to the cortex. In this review we outline the guiding process from the early growth of thalamic axons to their topographic targeting to specific cortical areas. 